\title{
C-REAKTIVE PROTEIN
}

\section{Budi Darmanta Sembiring}

Fakultas Kedokteran, Universitas Methodist Indonesia, Medan, Indonesia

Email: budidarmantasbr@gmail.com

DOI: https://doi.org/10.46880/methoda.Vol11No1.pp35-39

\begin{abstract}
CRP which is produced in liver is an acute glycoprotein fase that concentrate will increase at the cell injury infection or inflammation. CRP can be use as predictor to primary risk or the second prevention to the heart disease and as a medical evaluation and has prognostic value. The time of CRP checking becomes important to know how long has been happened the disease risk. The CRP measurement can be done by latex-by-latex Agglutination Assay method, Immunoassay dan High Sensitivity C-Reaktif Protein (hs-CRP).
\end{abstract}

Keywords: CRP, Latex Agglutination, Immunoassay, hs-CRP.

\begin{abstract}
ABSTRAK
CRP yang diproduksi di hati merupakan suatu glycoprotein fase akut yang konsentrasi akan meningkat pada cedera jaringan, infeksi atau inflamasi. CRP dapat digunakan sebagai predictor terjadinya resiko primer maupunpencegahan sekunder terhadap penyakit jantung dan juga sebagai evaluasi pengobatan dan mempunyai nilai prognostic. Waktu dilakukannya pemeriksaan CRP menjadi penting untuk mengetahui berapa lama sudah terjadi resiko penyakit. Pengukuran CRP dapat dilakukan dengan Metode Latex Agglutination Assay, Immunoassay dan High Sensitivity C-Reactive Protein ( $h s-C R P)$.

Kata Kunci: $C R P$, Latex Agglutination, Immunoassay, hs-CRP.
\end{abstract}

\section{PENDAHULUAN}

C-Reaktive Protein adalah suatu protein fase akut yang terdapat dalam sirkulasi orang sehat dalam jumlah kecil $=1 \mathrm{ng} / \mathrm{L}$. Sebagai akut fase protein konsentrasinya dapat meningkat 100x atau lebih pada cedera jaringan, infeksi atau inflamasi. CRP diproduksi oleh sel hepatosit hati sebagai respon terhadap sitokin IL-1, IL-6 dan TNF $\alpha$. CRP pertama kali di diskripsikan oleh William Tilled dan Thomas Francis di institut Rockefeller pada tahun 1930 (Indro, 2004; McPherson \& Pincus, 2007). CRP meningkat tajam setelah terjadi reaksi radang akut atau cedera jaringan 6-8 jam, mempunyai waktu paruh 19 jam dan dalam waktu 24-48 jam telah mencapai puncaknya. CRP tidak berpengaruh terhadap variasi diurnal. Oleh karena itu CRP sangat berguna untuk menegakkan diagnosa inflamasi dan penyakit infeksi.

Pengukuran CRP Dapat menjadi prediktor resiko yang primer dan pencegahan sekunder untuk penyakit serebrovaskular dan bisa memprediksi nilai prognostiknya.

CRP adalah anggota keluarga dari protein Pentraksin, yaitu suatu protein pengikat kalsium dengan sifat perubahan imunologis. Gen yang menyandi CRP terletak di 
kromosom 1. Molekul CRP terdiri dari 5-6 subunit polipeptida non glikosilat yang identik, terdiri dari 206 residu asam amino, dan berikatan satu sama lain secara non kovalen membentuk suatu molekul berbentuk cakram (disk) dengan berat molekul 110-140 kDa, setiap unit mempunyai berat molekul $23 \mathrm{kDa}$.

C-Reaktif Protein adalah suatu glycoprotein serum abnormal yang di produksi oleh hati setelah di modulasi oleh sitokin pada keadaan inflamasi akut, baik oleh karena infeksi maupun penyebab non infeksi dan beberapa proses keganasan (Kosasih \& Kosasih, 2008; Roit, 2003). Sintesa CRP dan protein fase akut lainnya di hati di modulasi oleh sitokin, IL -1b, IL-6 dan TNF- $\alpha$ merupakan regulator yang sangat penting pada sintesa CRP.

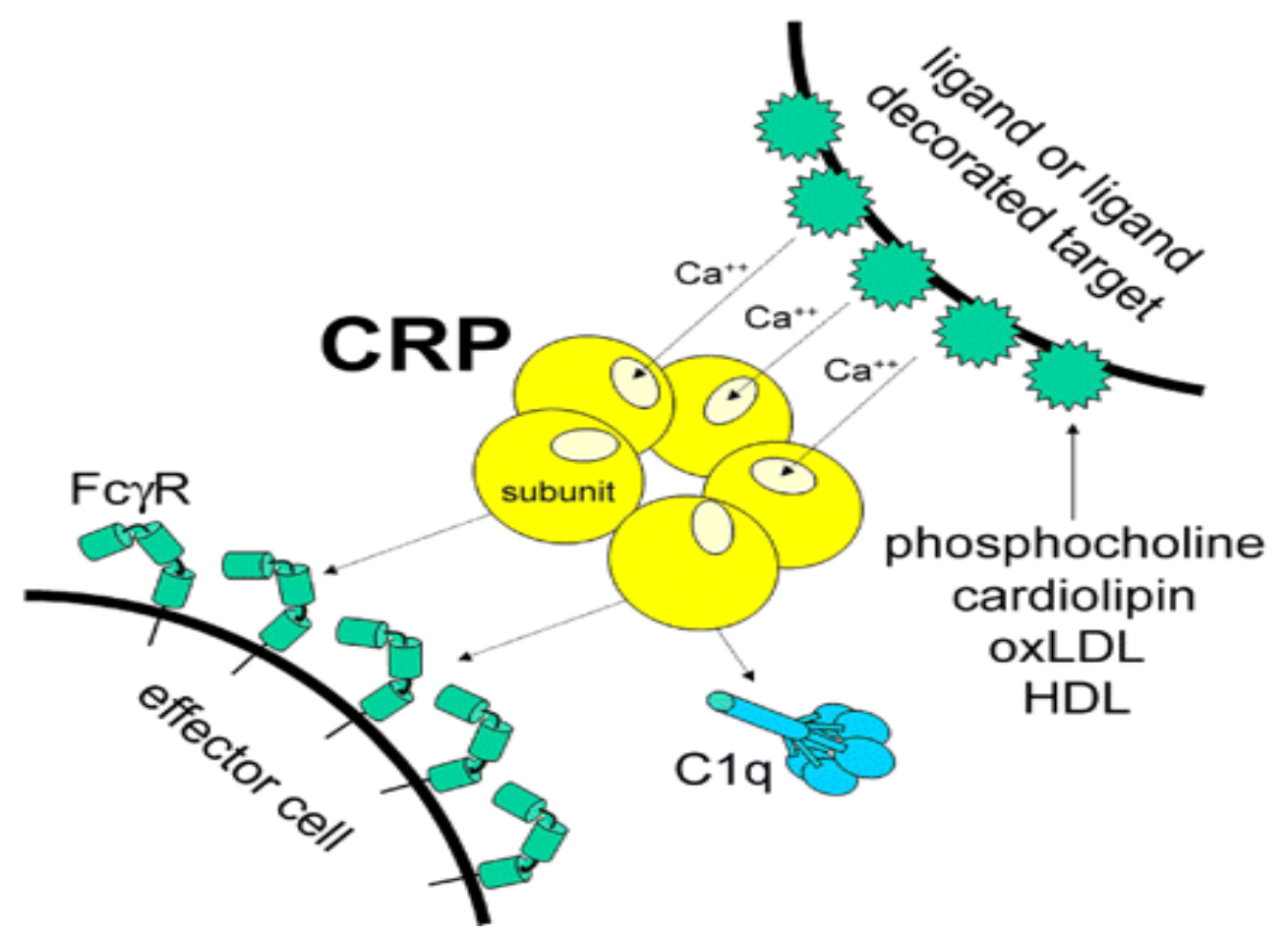

Gambar 1. Sintesa CRP

CRP pertama kali di diskripsikan oleh Tilled dan Francis pada tahun 1930 (Indro, 2004; McPherson \& Pincus, 2007). Mereka menyebutkan bahwa sera penderita infeksi akut akan membentuk presipitat dengan ekstrak non-protein dari Pneumococcus yang dikenal sebagai C-Polysaccharide yang mengandung ion kalsium. Protein yang menyebabkan reaksi presipitasi ini dinamakan C-Reactive Protein (CRP).

Selama inflamasi akut (infeksi dan non infeksi) dan beberapa proses keganasan, kadar CRP di dalam serum penderita akan meningkat sebagai suatu fenomena nonspesifik, dalam waktu 4-6 jam setelah timbul respon fase akut dengan waktu paruh (half live) 4-7 jam dan mencapai kadar puncak $100-1000 \%$ dari kadar base line dalam waktu 3-7 hari (Indro, 2004).

CRP di duga berperan pada innate system immune (Di Napoli, Papa, \& Bocola, 2001). Seperti juga immunoglobullin G (IgG) CRP mengaktifkan komplemen, berikatan pada $\mathrm{Fc}$ reseptor, berperan penting pada pembentukan sitokin proinflamatory yang meningkatkan reaksi inflamasi. CRP dapat mengubah molekul "self" dan molekul asing berdasarkan pola pengenalan. Dengan demikian CRP berperan sebagai molekul 
pengawas terhadap molekul "self' yang telah berubah dan sebagai molekul patogen.

Pengenalan ini membentuk suatu pertahanan dini dan berperan sebagai signal proinflammatory dan mengaktifkan immun humoral, adaptive. Jadi beberapa peran CRP dapat disebutkan: inisiasi, proses opsonisasi dan fagositosis, mengaktifkan komplemen, makrofag, neutrofil dan monosit. CRP berperan berperan penting pada pengenalan organisme mikrobial dan sebagai immunomodulator pada sistem pertahanan tubuh, CRP juga berperan pada pengenalan jaringan nekrotik (Morrow, 2010).

CRP dapat terikat pada sel-sel apoptotik, melindungi sel dari pertemuan dengan komponen terminal dari komplemen dan membantu respon anti-inflamatory innate system immune (Gambino, 1997). Peningkatan sintesis CRP akan meningkatkan viskositas plasma sehingga laju endap darah juga akan meningkat. Adanya CRP yang tetap tinggi menunjukkan infeksi yang tetap (Benitz, Han, Madan, \& Ramachandra, 1998).

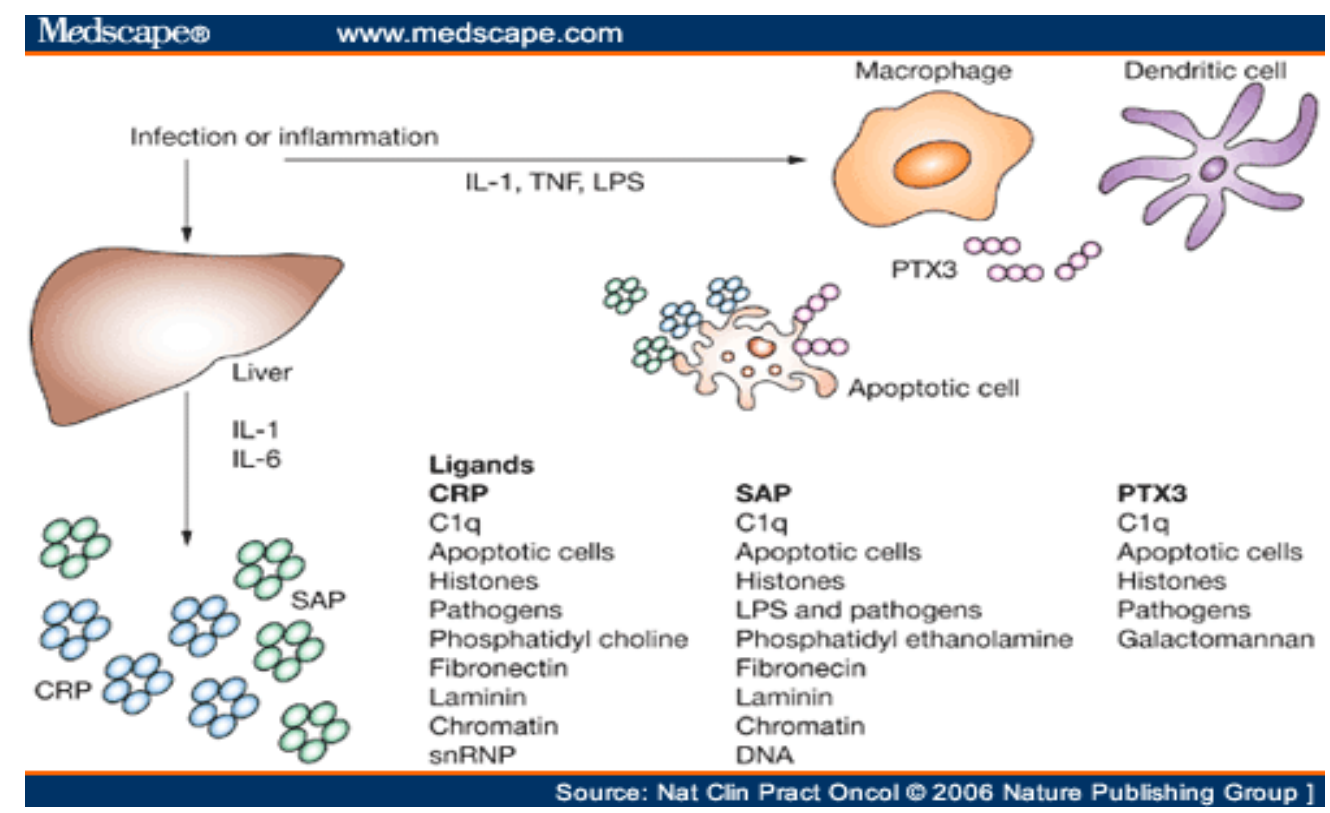

Sumber: Nature Clinical Practice Oncology

Gambar 2. Infection atau Inflammation

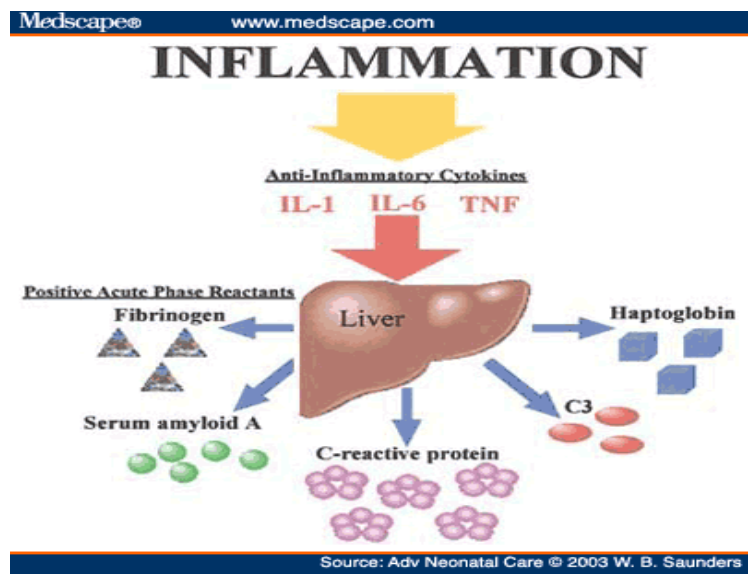

Sumber: Nature Clinical Practice Oncology

Gambar 3. Inflammation

\section{INDIKASI}

Penentuan CRP dipakai untuk membantu menegakkan diagnosis dari keadaan penyakit yang bersangkutan dengan proses peradangan dan nekrosis jaringan, juga memantau hasil pengobatan (effectiveness of therapy) dari beberapa penyakit dengan radang akut atau kerusakan jaringan, selain itu juga sebagai penanda inflamasi pada penyakit kardiovaskuler untuk melihat kemungkinan adanya serangan penyakit jantung coroner dan menambah informasi 
mengenai factor resiko tradisional (Antuzzi \& Braunschweig, 2014).

\section{METODE PEMERIKSAAN C- REAKTIVE PROTEIN}

\section{Latex Agglutination Assay}

Precipitation assay dan agglutination assay merupakan metode traditional yang digunakan untuk pemeriksaan CRP. Latex agglutination assay adalah suatu test kualitatif dengan batas kemampuan deteksi kira-kira $10 \mathrm{mg} / \mathrm{L}$ sebagai upper- limit normal. Oleh karena kadar CRP dapat meningkat secara cepat) dan dramatis, reaksi false-negative sering terjadi akibat prozonetype phenomenone (McPherson \& Pincus, 2007).

Hasil dinyatakan dengan kwalitatif.

\section{Imunoassay}

Antibodi yang sangat sensitif telah dikembangkan untuk pemeriksaan CRP berupa assay yang bersifat rapid, spesifik dan sangat sensitif. Imunoassay (RIA) dan enzyme Imunoassay (EIA) dapat digunakan untuk pemeriksaan CRP pada berbagai keadaan klinis.

Shapiro dan Shenkin melaporkan bahwa metode immunoradiometric assay (IRMA) dengan radial imunodiffusion dan enzyme multiplied imunoassay masih sensitif pada kadar CRP serum 0,5 $\mu \mathrm{g} / \mathrm{L}$ dengan presisi yang baik, reference range untuk orang dewasa normal 0,05-4,0 mg/L.

Dengan menggunakan Double Antybody Sandwich ELISA. Antibodi pertama (antibodi pelapis) dilapiskan pada fase padat, kemudian ditambahkan serum penderita. Selanjutnya ditambahkan substrat, dan reagen penghenti reaksi. Hasilnya dinyatakan secara kuantitatif.

\section{High Sensitivity C-Reaktive Protein (hs- CRP)}

Saat ini telah dikembangkan suatu pemeriksaan CRP yaitu dengan tekhnik ultrasensitive immunoturbidimetry, Assay baru ini dapat memeriksa adanya peningkatan turbidity bentuk kompleks antigen-antibodi bila sampel serum (antigen) di campur dengan reagen (antibodi) membentuk suatu kompleks imun. Assay ini mempunyai sensitivity $0,1 \mathrm{mg} / \mathrm{L}$. Kekeruhan (turbidity) yang terjadi sebagai akibat ikatan tersebut diukur secara fotometris. Konsentrasi dari CRP ditentukan secara kuantitatif dengan pengukuran turbidimetric (McPherson \& Pincus, 2007).

\section{FAKTOR-FAKTOR YANG DAPAT MEMPENGARUHI HASIL PEMERIKSAAN CRP}

Sebagaimana semua test serologik, hemolitik, lipemik, atau turbid sera dapat menyebabkan hasil pemeriksaan yang salah, sehingga tidak dapat digunakan. Faktor faktor demografis seperti umur, jenis kelamin, dan ras harus di sesuaikan dengan nilai upper reference limit dari CRP.

Berikut adalah penyakit- penyakit yang dapat meningkatkan kadar CRP: Demam Rematik Akut, Rheumatoid Arthtritis, Infark Miokard Akut, Infeksi Pasca Operasi, Bakteri, Virus dan Sepsis. Sedangkan yang dapat menurunkan kadar CRP: Inhibitory cytokines, Exercise, Pemakaian Obat-obatan seperti Non-Steroid, Anti Inflamasi, Salisilat dan Statin.

\section{KESIMPULAN}

C-Reactive Protein (CRP) adalah protein, ditemukan dalam darah dimana dia menunjukkan adanya proses "peradangan". CRP dihasilkan dalam hati dan selama infeksi, dan dengan beberapa bentuk kanker dan penyakit inflamasi (rheumatoid arthritis, 
lupus) dia dapat meningkat pada tes darah. CRP juga dapat meningkat bila ada peradangan pada arteri jantung dan merupakan marker untuk coronary artery disease.

\section{DAFTAR PUSTAKA}

Antuzzi, G., \& Braunschweig, C. (2014). Adipose Tissue and Adipokines in Health and Disease. Berlin: Springer.

Benitz, W. E., Han, M. Y., Madan, A., \& Ramachandra, P. (1998). Serial Serum C-Reactive Protein Levels in the Diagnosis of Neonatal Infection. Pediatrics, 102(4), e41-e41. https://doi.org/10.1542/peds.102.4.e41

Di Napoli, M., Papa, F., \& Bocola, V. (2001). C-Reactive Protein in Ischemic Stroke: an Independent Prognostic Factor. Stroke, 32(4), 917-924.

Gambino, R. (1997). C-Reactive Protein Undervalued, Underutilized. New York: Oxford University Press.

Indro, H. (2004). Imunoasai Terapan pada Beberapa Penyakit Infeksi (Edisi Pert). Surabaya: Airlangga University Press.

Kosasih, E. N., \& Kosasih, A. S. (2008). Tafsiran Hasil Pemeriksaan Laboratorium Klinik (Edisi Kedu). Jakarta: Karisma Publishing Group.

McPherson, R. A., \& Pincus, M. R. (2007). Henry's Clinical Diagnosis and Management by Laboratory Methods (Clinical Diagnosis \& Management by Laboratory Methods). Amsterdam: Elsevier Inc.

Morrow, D. A. (2010). Cardiovascular Biomarkers: Pathophysiology and Disease Management. Berlin: Springer Science \& Business Media.

Roit, I. (2003). Protein-Protein Fase Akut dalam Essential Imunologi (Edisi Kede). Jakarta: Penerbit Widya Medika. 